\title{
Bushmeat and zoonoses threats warrant need for national zoonoses combat inter-disciplinary research partnership, evolving citizen science and policy ban of trade and consumption
}

Sir,

"We must find them before they find us" said Dr.Shi, Bat Virologist". Indian bat species diversity stands 127 ssp and China 147 bat ssp. ${ }^{1,2}$ Indian publications online (2000-2020), searching "bat", "Chiroptera", "India", retrieved results viz., 191 (Elsevier); 27 (Scopus) and 0 (Wiley). For China, 594 publications exist (2000-2017)2; Himalayan cave bat biodiversity is not systematized, average annual deforestation rate, from 2000 to 2014 being $0.5 \%$ (Bhutan, Nepal) but $1.3 \%$ in India, China. ${ }^{3}$ "Dilution effect", so-called "negative diversity-disease", says 'biodiversity losses promote disease transmission'. ${ }^{4}$ Protecting natural areas from human incursion reduces zoonotic disease spillover. ${ }^{5}$ Emergence of bat coronavirus represents recent viral explosion reaction to declining biodiversity. ${ }^{6}$ Meta-analysis of 143 hunting studies from India showed 114 mammal species but bat-hunting data absent. $^{7}$

In 2019-nCoV was $96 \%$ identical (whole-genome level) to bat coronavirus. ${ }^{8}$ WHO claims that $60 \%$ human diseases originated in animals. 1.67 million unknown viruses exist with infection capability on humans, birds and animals (live science report). Admitting lack of research on risk assessment, mandatory national monitoring of wild animal health is needed and this chronic vacuum must get filled, detecting, preventing control against zoonotic threats, minimizing public health risks. Power of Science zeroing into sources of infection pictures cross-chains of inter-species transmission. Zoology Departments, nation, worldwide can share preserved bat samples (under Nagoya protocol on access and benefit sharing-ABS), as referencing standard gene sequences, comprehending molecular shifts in wild today. Fast population-growing India, China, Brazil, Mexico, Nigeria, Indonesia, Bangladesh, etc are next zoonoses hotspots. Mankind, intruding into animal spaces reacts, making emergence of new infectious diseases.

SARS-CoV-2 origin, plausibly explained as (i) natural selection in animal host before zoonotic transfer; and (ii) natural selection within humans, post-zoonotic transfer. ${ }^{9}$ Retrospective investigations traced patient zero for 20132016 West African Ebola virus disease outbreak to batmingling by Guinea villager and reducing human contact with high-risk species and instituted surveillance traceability phenomenal systems for low-risk zoonotic infection recommended. ${ }^{10,11}$ Evidencing bat $\mathrm{CoV}$ first,
200 novel bat CoVs were identified and $35 \%$ sequenced bat virome-composing CoVs. ${ }^{12,13}$ Feeble research is on bat-borne viruses, insect foodweb vectors in hunted bats of northeast Nagaland. 24.5-km long Krem Puri, Meghalaya cave bat diversity is absolutely lacunae. Nipah virus zone isolation of Tioman virus was reported in West Bengal, Assam from Pteropus giganteus bat. ${ }^{14}$ Nagaland traditional bat harvests showed paramyxovirus positive bat-tissue samples with critically human sera samples serologically-positive for filoviruses, demonstrating likely human exposure to filoviruses 15 . Globally, alphacoronavirus HCoV-NL63 and betacoronavirus HCoV-HKU1 were discovered from bats, rodents. ${ }^{16} \mathrm{IBV}$, IBV-like $\mathrm{CoV}$-strains are detected from gallinaceous and non-gallinaceous birds asymptomatically acting as global wild reservoir, spreading IBV-like CoV-strains. ${ }^{17}$ Animal-to-human transmission frequency of viruses increased with $\mathrm{CoVs}$ and genetically, biologically, different zoonoses-potent viruses (Ebola, Influenza, Flavi, Hendra and Nipah viruses). Chinese strain Ro-BatCoV GCCDC1 356 was identified on fruit-bat stools, Rousettus leschenaultii, (Pteropodidae) in 2014. ${ }^{18}$ Though no direct progenitor of SARS-CoV is found in bats, RNA recombination is plausible within bat cave (Yunnan, China) evidencing high CoVs diversity, implying presence of all genetic elements to form SARS-CoV19.

Bats and Naga community harmonized centuries until economic globalization, cross-border trade ignited reactivity. Prof. Johannes Vogel, Director-General, Museum of natural history, Leibniz Institute for evolution \& biodiversity research; Professor-Humboldt University rightly said, "a global economic system based upon exploitation of nature will fail". Poor zoonotic pathogen pathway knowledge in India's wildlife and occurrence upon interfacing populations, critically-linking forest ecosystems warrants exigent addressal. Bushmeat comprised ungulates (ox, pigs, deer); camelidae (camels); rodents (mice, rat, squirrel, porcupine); ratites (Kiwi, ostrich); reptiles (lizards, snakes, turtles and crocodiles); agamidae (Iguans); leporidae (rabbits); Phasianidae (Quails); chiroptera (bats); suidae (boar); corvidae (Crows); columbidae (Doves, Pigeons), Galliformes (Fowls); anatidae (Ducks); indigenous aquatic avifauna (Egrets, Herons, Cormorants); migratory birds (storks, pelicans) etc. 
Surveying stakeholder bushmeat consumption statistics, monitoring clinical symptoms and patterns of drug sensitivities for disease prevention and therapeutic efficiency control is decisive as web-of-science yielded no consumption data. Funding for tribal health-watch and combing sentinel networks is critical on focal outbreaks amongst forest product-gatherers. National review workshop on published disease vector threats and risks prevalent amongst wild fauna to quantify quantum of infectious disease burden through bushmeat be organized. Updated vaccine response pattern to combat regionspecific zoonoses be reported to e-cloud umbrella, referencing prevention, control for better response planning, policy decision-making for citizen health and bio-defensive control. Research attention on invisibly cryptic zoonoses, unresolved pathogenicity with exclusive or predominant anthroponotic transmission patterns is wanting. Improved community awareness about bushmeat risk factors, developing national zoonoses combat partnership for health assurance from grassroots is indispensable and crucially, a new Ministry of science popularization ought to be established.

It is life-redemptive measure to initiate, strengthen, enforce national ruling for promulgating criminalization of bushmeat meat trading, consumption in India which should overrule proven, unproven COVID-19 connections, accounting grave risk upon two-thirds villagers of 1.3 billion. Legal trading of wildlife resources should cease. Handling, hunting, poaching any wildmeat species under sustenance pretext should end. Tourists who contracted asymptomatic zoonotic pathogens by consumption, contact-touching, photography, tree-hut camp-trekking, bearing newer viral signatures must get retinal-imaged, e-filed before departure. Devitalisation treatment protocols (rendering epibiota non-viable) are compulsory for bat-favored, trans-continental transit of bugs, beetles, forest seeds, pods, roots, barks, soils, agave, cacti flowers \& fruits and bio-packing materials also e.g., seaweeds). Development of citizen science on social safety network is necessary to safeguard national wildlife, farmed livestock, inhabitants; to refrain from contacting dead animals or dispose as per health official intervention. When bushmeat sharing, trading is halted, nation-wide consumption outlawed, we need to color code-map potentially-wild reservoirs testing positive for SARS-CoV-2, showing asymptomatic biomes, helping evolution of right loci-centric vaccines, antiviral therapies against common $\mathrm{CoV}$-infections, serving as protective advisory flyer for forest-bathing tourists.

People' sciences ended an epidemic in Africas as communities learnt and self-framed isolation measures, bylaws controlling movement. ${ }^{20}$ Ending tribal consumption of bat-bitten fruits, bat fecal dung collection, domestication-proximity to live-traded wild animals, pleasure-slaughter or charcoal-grilling pays. Indian folk medicine uses Dabb lizards, Squirrel, bats, Chameleons, Iguanas etc. Urban-dwellers must stop petraising wild non-human primates, rodents and birds through National security-driven zoonoses prevention vulnerable Species Utilization Ban Act. Emotionallywashing, cryptic virulent, asymptomatic dead human and animals must stop. Educating tribal societies through health-workers promotes responsible, bio-secure citizen science, averting newer catastrophes. Continual geostationary pooling of asymptomatic reaction allergies of bushmeat (triggered by immune system) and asymptomatic sensitivity (indicative antibodies without symptomatic responses) into e-cloud registry helps healthier amendment of early pharmacotherapeutic doses, salvaging human lives. Better citizen science promotion policies halting forest clearance, reducing man-nature interaction in wild for better climates, closing unregulated markets, changing food consumption practices are imperative, finding obscure, transmission passages and patch-sealing them to nip new zoonoses threats and bettering Indian lives. Similar to the efficient cartagena protocol on biosafety to the convention on biological diversity (against living modified organisms), within India, holistic national biosecurity renaissance Act-2020 could shield, defend and assure healthy monitoring, control and response to Epizootic diseases, rethinking and reinventing how man interacts with nature.

Ansu Thomas*

Attatharayil, Edappavoor, Ayroor, Pathanamthitta, Kerala, India

*Correspondence to

Dr. Ansu Thomas,

E-mail: dransuthomas@gmail.com

\section{REFERENCES}

1. Talmale S, Saikia U, Version 2.0. A Checklist of Indian Bat Species (Mammalia: Chiroptera), Zoo Surv India. 2018.

2. Feijó A, Wang Y, Sun J, Li F, Wen Z, Ge D, et al. Research trends on bats in China: A twenty-first century review, Mammal Biol. 2019; 98:163-72.

3. Brandt JS, Allendorf T, Radeloff V, Brooks J. Effects of national forest-management regimes on unprotected forests of the Himalayas. Conserv Biol. 2017;31(6):1271-82.

4. Keesing F, Belden LK, Daszak P, Dobson A, Harvell CD, Holt RD, et al. Impacts of biodiversity on the emergence and transmission of infectious diseases. Nature. 2010;468:647-52.

5. Rohr JR, Civitello DJ, Halliday FW, Hudson PJ, Lafferty KD, Wood CL, Mordecai EA Towards common ground in the biodiversity-disease debate. Nature Ecol. 2020;4:24-33.

6. Morand S. La Prochaine Peste. Une histoire globale des sociétés et de leurs épidémies. 2016; Editions Fayard, Paris.

7. Velho N, Karanth KK, Laurance WF. Hunting: A serious and understudied threat in India, a globally 
significant conservation region, Biol Conserv. 2012;148:210-5.

8. Zhou P, Yang X, Zheng-Li Shi. A pneumonia outbreak associated with a new coronavirus of probable bat origin, Nature. 2020;579:270-3.

9. Andersen KG, Rambaut A, Ian Lipkin W, Holmes EC, Garry RF. The proximal origin of SARS-CoV2, Nature Medicine. 2020;26:450-5.

10. Marí Sáez A, Nowak K, Lapeyre V, Zimmermann F, Dux A, Kuhl HS, et al. Investigating the zoonotic origin of the West African Ebola epidemic. Mol Med. 2015;7:17-23.

11. Formenty P, Epelboin A, Allarangar Y, Libama F, Boumandouki P, Koné L, et al. Séminaire de formation des formateurs et d'analyse des épidemies de fièvres hémorragiques due au virus Ebola en Afrique centrale de 2001 à 2004. Santé Publique. 2004;244-54.

12. Poon LLM, Chu DK, Chan KH, Wong OK, Ellis TM, Leung YHC, et al. Identification of a novel coronavirus in bats. J Virol. 2005;79:2001-9.

13. Chen L, Liu B, Yang J, Jin Q. DBatVir: The Database of Bat-associated Viruses. 2014.

14. Yadav P, Sarkale P, Patil D, Shete A, Kokate P, Kumar V, Jain R, et al. Isolation of Tioman virus from Pteropus giganteus bat in North-East region of India. Infection, Genet and Evol. 2016;45:224-9.

15. $\mathrm{Br} \mathrm{A}$, Dovih $\mathrm{P}$, Ramakrishnan U, LiangE., Mendenhall I, Wen Hong DL, Smith GJD. Evidence of filovirus and henipavirus in bats and bat harvesters, India. Intl J Infect Dis. 2019;79(S1):1150.

16. Tao Y, Shi M, Chommanard C, Queen K, Zhang J, Markotter W, et al. Surveillance of bat coronaviruses in Kenya identifies relatives of human coronaviruses NL63 and 229E and their recombination history. J Virol. 2017;91:e01953-16.

17. Cavanagh D. Coronaviruses in poultry and other birds. Avian Pathol. 2005;34:439-48.

18. Huang C Liu, WJ, Xu W, Jin T, Zhao Y, Song J, Shi Y, Ji W, Jia H, Zhou Y, et al. A bat-derived putative cross-family recombinant coronavirus with a reovirus gene. PLoS Pathog. 2016;12:e1005883.

19. Ge XY, Li JL, Yang XL, Chmura AA, Zhu G, Epstein JH. Isolation and characterization of a bat SARS-like coronavirus that uses the ACE2 receptor. Nature. 2013;503:535-8.

20. Richards P. Ebola: How a People's Science helped end an epidemic. 2016. Zed Books, London. Available at: https://anthrosource.onlinelibrary.wiley.com/doi/abs /10.1111/aman.12854

Cite this article as: Thomas A. Bushmeat and zoonoses threats warrant need for national zoonoses combat inter-disciplinary research partnership, evolving citizen science and policy ban of trade and consumption. Int J Sci Rep 2021;7(1):68-70. 